\title{
DETERMINATION OF FREE URINARY CORTISOL IN CUSHING'S SYNDROME USING REVERSED-PHASE HIGH PERFORMANCE LIQUID CHROMATOGRAPHY
}

\author{
Eduardo Kinio Sugawara*, Luciane Maria Ribeiro Neto e Ieda Terezinha do Nascimento Verreschi \\ Departamento de Medicina, Universidade Federal de São Paulo, Rua Pedro de Toledo, 781, 04039-032 São Paulo - SP, Brasil
}

Recebido em 29/10/08; aceito em 21/7/09; publicado na web em 12/1/10

\begin{abstract}
Determination of free urinary cortisol is a test of choice in the diagnosis of Cushing's syndrome. In this study, cortisol was quantified using reversed-phase high-performance liquid chromatography (RP-HPLC) in urine samples previously extracted with ether and using triamcinolone acetonide as internal standard (IS). A BDS-Hypersil-C18 ${ }^{\circledR}$ column, water-acetonitrile (72:28; v/v), with a flow rate of $1.0 \mathrm{~mL} / \mathrm{min}$ and detection at $243 \mathrm{~nm}$ were used. This method showed to be both effective and efficient, with sensitivity and linearity ranging from 2.50 to $150 \mu \mathrm{g} / \mathrm{L}$, and can be used in substitution to the radioimmunoassay technique within this concentration range.
\end{abstract}

Keywords: HPLC; cortisol; urine.

\section{INTRODUCTION}

Cortisol (F) determination in the different organic fluids has been used as a diagnostic aid in several pathologies as well as in clinical research studies.

Measurements of free $\mathrm{F}$ in urine and of $\mathrm{F}$ and corticotropin (ACTH) in plasma are tests of choice in the diagnosis of Cushing's syndrome.

Cushing's syndrome is a hormonal disorder caused by prolonged exposure of the body tissues to high levels of the hormone cortisol. Sometimes called hypercortisolism, Cushing's syndrome is relatively rare and most commonly affects adults aged 20 to 50 years. People who are obese and have type 2 diabetes, along with poorly controlled blood glucose and high blood pressure, have an increased risk of developing the disorder. ${ }^{1}$

Historically, several methods using the radioimmunoassay technique (RIA) were developed to determine F. This technique is still susceptible to cortisone interference and/or other endogenous steroidal metabolites and synthetic glucocorticoids. ${ }^{2}$ Another limitation of the RIA techniques is the impossibility of using an internal standard to monitor the recovery of $\mathrm{F}$ in the extraction process. Recent reviews comparing RIA with chromatographic methods in the determination of F clearly indicate that more accurate results are obtained with the latter. ${ }^{3-7}$ Limitations such as those observed using RIA in F determination led to the development of more specific methods based on liquid chromatography with ultraviolet detection (HPLC-UV), ${ }^{7-11}$ liquid chromatography combined with mass spectrometry (LC-MS) ${ }^{5,7,12}$ and gas chromatography combined with mass spectrometry (GC-MS). ${ }^{13-15}$ LC-MS/MS methods are among the most successful approaches to improve specificity problems inherent in many immunoassays. The latest generation of tandem mass spectrometers has superior limits of quantification, permitting omission of previously employed derivatization steps. ${ }^{16,17}$ Chromatographic methods have enabled interferent reduction not only in the quantification of cortisol, but also of cortisone and endogenous F metabolites.

In this study, a method was developed to quantify free $\mathrm{F}$ in urine using reversed-phase high-performance liquid chromatography (RP-HPLC) after liquid-liquid extraction ${ }^{18,19}$ and using triamcinolone acetonide $(\mathrm{T})$ as internal standard.

*e-mail: du-kinio@hotmail.com

\section{EXPERIMENTAL}

\section{Reagents}

Cortisol (98\%) was provided by Sigma-Aldrich (St. Louis, MO, USA) and Triamcinolone acetonide (100\%) by USP (Rockville, MD, USA). Methanol and acetonitrile were HPLC grade, and ether was analytical reagent grade (Merck, Darmstadt, Germany). Water was obtained with a Milli-Q purification system (Millipore, Bedford, MA USA). Both acetic acid (Merck, Darmstadt, Gemany) and sodium hydroxide (Vetec, Rio de Janeiro, Brazil) were used in 10\% solutions.

\section{Standards}

Standard solutions $\left(0.01,0.10,10.0\right.$, and $\left.100 \times 10^{1} \mu \mathrm{g} / \mathrm{mL}\right)$ of $\mathrm{F}$ and $\mathrm{T}$ were prepared in methanol and stored at $-20{ }^{\circ} \mathrm{C}$. Triamcinolone acetonide was used as internal standard in the chromatographic analyses.

\section{Sample preparation}

Urine samples $(5.0 \mathrm{~mL})$ added with $\mathrm{T}(40.0 \mathrm{ng} / \mathrm{mL})$ were extracted with ether $(3.0 \mathrm{~mL})$ by shaking in Vortex ${ }^{\circledR}$ and then centrifuged $\left(2.1130 \mathrm{~g}, 15 \mathrm{~min}, 4^{\circ} \mathrm{C}\right)$. The organic phase was evaporated under a nitrogen stream. The residue was resuspended in the mobile phase $(200 \mu \mathrm{L})$, filtered through a membrane (Durapore ${ }^{\circledR}, 0.45 \mu \mathrm{m}, 13 \mathrm{~mm}$; Millipore, São Paulo, BR) and injected $(50.0 \mu \mathrm{L})$ onto the chromatographic column.

Optimal $\mathrm{pH}$ for extraction was determined through sample recovery tests with a known concentration $(50.0 \mu \mathrm{g} / \mathrm{L})$ of $\mathrm{F}$ in acid (5.0), neutral (7.0), or alkaline (9.0) $\mathrm{pH}$, adjusted with acetic acid or sodium hydroxide.

\section{RP-HPLC}

A HP 1100 high-performance liquid chromatograph (HewlettPackard, Palo Alto, CA, USA) consisting of an automatic sampler, a quaternary pump and variable-wavelength $(\lambda=243 \mathrm{~nm}) \mathrm{UV}$ detector was used. Chromatographic separations were accomplished with a

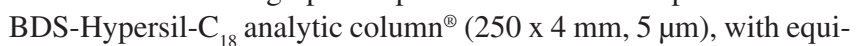
valent guard-column, obtained from Agilent (USA), and maintained at $40{ }^{\circ} \mathrm{C}$ during analysis. Water-acetonitrile (72:28; v/v) was used as 
mobile phase with a flow rate of $1.0 \mathrm{~mL} / \mathrm{min}$ for $9.0 \mathrm{~min}$, and 1.5 $\mathrm{mL} / \mathrm{min}$ for $6.0 \mathrm{~min}$. At $15.0 \mathrm{~min}$, the mobile phase was changed to acetonitrile (100\%), which was maintained for $2.0 \mathrm{~min}$. At $17 \mathrm{~min}$, the initial condition was reestablished and maintained for another 3 min, for a new chromatographic run.

\section{Calibration curve}

A calibration curve for $\mathrm{F}$ quantification was determined in aqueous media by adding methanolic standard solutions of nine different concentrations of $\mathrm{F}(2.50,5.00,10.0,15.0,25.0,50.0,70.0$, 100 , and $150 \mu \mathrm{g} / \mathrm{L})$ and $\mathrm{T}(40.0 \mathrm{ng} / \mathrm{mL})$. The curve was obtained using the experimental data from the graph representing the ratio between the peak areas of $\mathrm{F}$ and $\mathrm{T}$ versus different concentrations.

\section{Analytical validation}

Linearity was evaluated by repeated $(n=5)$ analysis using different concentrations in the range from 2.50 to $150 \mu \mathrm{g} / \mathrm{L}$. The relative standard deviation (RSD) was determined for each concentration, and the limit of quantification was defined as being the lowest concentration with RSD $\leq 10 \%$. Intra-assay precision was determined using samples added with different concentrations $(2.50$ to $150 \mu \mathrm{g} / \mathrm{L})$ and analyzed in replicate $(n=5)$. Inter-assay precision was evaluated in different concentrations for two and three consecutive days. The method accuracy was assessed by analyzing samples $(\mathrm{n}=5)$ with known concentrations prepared in the laboratory, using calibrated equipment and glassware. The results were expressed as percentages.

The $\mathrm{F}$ and $\mathrm{T}$ standard solution samples used to determine these parameters were prepared with water. Matrix interference was verified using urine from healthy individuals added with known concentrations of $\mathrm{F}(5.00,10.0,70.0$, and $100 \mu \mathrm{g} / \mathrm{L})$.

\section{Sampling}

The applicability of the method was evaluated by analyzing samples $(n=30)$ from the laboratory routines of the Steroids Laboratory of the Endocrinology Division (Medicine Department of the Federal University of São Paulo) and the Hormones and Molecular Genetics Laboratory (LIM/42) of the Endocrinology Division (Medical School of the University of São Paulo). Urine samples were stored at -20 ${ }^{\circ} \mathrm{C}$ until analysis.

\section{RESULTS AND DISCUSSION}

The method used here, RP-HPLC, was shown to be fast and efficient for determining free urinary $\mathrm{F}$. The retention times of $\mathrm{F}$ and $\mathrm{T}$ were 7.3 and $14.1 \mathrm{~min}$, respectively. The total time for chromatographic analysis was $20 \mathrm{~min}$. The retention time was consistent with or inferior to the times reported in the literature, all superior to 20 min. ${ }^{6,8,10}$ A typical chromatogram is depicted in Figure 1 (B). Ether extraction associates simplicity and low cost for RP-HPLC analysis. Furthermore, its use in extraction of steroids is frequently mentioned in the literature. ${ }^{18-21}$ No $\mathrm{pH}$ interference was observed in extraction recovery, once the relationship between $\mathrm{F}$ and $\mathrm{T}$ was maintained with the different $\mathrm{pH}$ values $(0.91 \pm 0.03)$. Replacing RIA by RP-HPLC allows a significant reduction in the total time of analysis, because the usually employed RIA methodology requires a minimum of $6 \mathrm{~h}$ for the incubation step. Moreover, this method confirms the methodology used for determination of serum cortisol ${ }^{22}$ in the routines of the Steroids Laboratory, contributing to laboratory practice and to the replacement RIA.
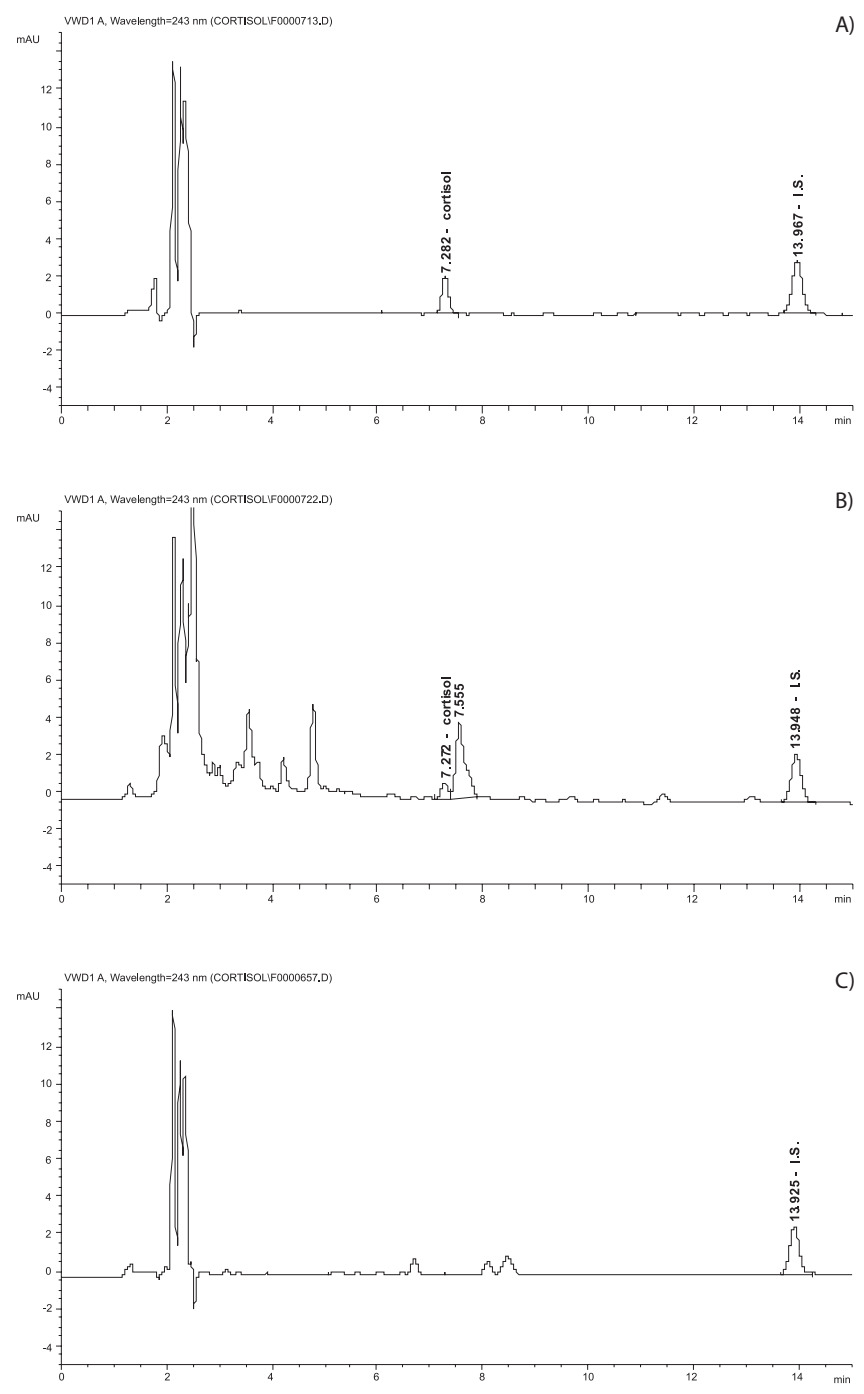

Figure 1. Characteristic analytical chromatogram of urinary free cortisol using RP-HPLC. (A) Added to water $25.0 \mu \mathrm{g} / \mathrm{L}$; (B) original urine sample (\# 8); and $(C)$ negative control. I.S.: Internal Standard (Triamcionolone Acetonide)

Table 1. Results of analytical validation obtained in the precision and accuracy study

\begin{tabular}{lccc}
\hline $\begin{array}{l}\text { Concentration } \\
(\mu \mathrm{g} / \mathrm{L})\end{array}$ & \multicolumn{2}{c}{ Precision $(\mathrm{RSD} \%)$} & Accuracy \\
& Intra-assay $(\mathrm{n}=5)$ & Inter-assay & $(\%)$ \\
\hline 2.50 & 3.10 & $\mathrm{ND}$ & $\mathrm{ND}$ \\
5.00 & 4.20 & $3.00(\mathrm{n}=2)$ & 114 \\
10.0 & 3.00 & $12.7(\mathrm{n}=3)$ & 90.6 \\
15.0 & 3.80 & $\mathrm{ND}$ & $\mathrm{ND}$ \\
25.0 & 7.70 & $5.00(\mathrm{n}=2)$ & 89.4 \\
50.0 & 0.70 & $\mathrm{ND}$ & $\mathrm{ND}$ \\
70.0 & 1.30 & $1.20(\mathrm{n}=2)$ & 88.9 \\
100 & 2.70 & $2.70(\mathrm{n}=3)$ & 95.9 \\
150 & 2.80 & $\mathrm{ND}$ & $\mathrm{ND}$ \\
\hline
\end{tabular}

ND: Not determined

Linearity was observed in the concentration range from 2.50 to 150 $\mu \mathrm{g} / \mathrm{L}$ with a determination coefficient $\left(\mathrm{r}^{2}\right)$ of 0.9944 , which meets the expected work range for a Cushing's syndrome diagnosis. Table 1 shows the precision and accuracy values obtained in the analytical validation study. The average values for the intra- and inter-assay RSD were $3.2 \%$ 
Table 2. Results of RP-HPLC measurements of free cortisol in urine (24 h), serum, and saliva samples of the same patients with an initial suspicion of autonomous cortisol secretion not confirmed by the suppression test (1 mg dexamethasone)

\begin{tabular}{lcccc}
\hline Sample & $\begin{array}{c}\text { Urinary free } \\
\text { cortisol } \\
(\mu \mathrm{g} / 24 \mathrm{~h})\end{array}$ & $\begin{array}{c}\text { Serum } \\
\text { cortisol } \\
(\mu \mathrm{g} / \mathrm{dL})\end{array}$ & $8 \mathrm{~h}$ & $23 \mathrm{~h}$ \\
\hline 1 & 37.1 & 1.60 & 66.5 & 527 \\
2 & 12.2 & 2.20 & 26.6 & 87.0 \\
3 & 12.4 & 2.10 & 51.0 & 178 \\
4 & 20.2 & 1.90 & 33.0 & 156 \\
5 & 35.7 & 1.10 & 92.6 & 122 \\
6 & 3.30 & 2.30 & 98.7 & 289 \\
7 & 16.4 & 1.10 & 7.00 & 212 \\
8 & 19.7 & $\mathrm{ND}$ & $\mathrm{ND}$ & $\mathrm{ND}$ \\
9 & 3.70 & $\mathrm{ND}$ & $\mathrm{ND}$ & $\mathrm{ND}$ \\
10 & 41.7 & 2.00 & 56.0 & 181 \\
11 & 19.8 & 1.20 & 7.00 & 301 \\
12 & 34.6 & 1.90 & 50.0 & 346 \\
\hline
\end{tabular}

Note: Free urinary cortisol samples \#8 and \#9 were from the same patients as samples \#6 and \#10, respectively.

(from 2.50 to $150 \mu \mathrm{g} / \mathrm{L}$ ) and $4.6 \%$ (from 5.00 to $100 \mu \mathrm{g} / \mathrm{L}$ ), respectively. These findings were compatible with those reported in the literature for the same concentration range, reported to vary around $7.0 \% .^{5,6,23}$ The accuracy of the method is between 88.9 and $114 \%$, which is also compatible with the reports of the literature showing values between 88 and $97 \% .5,24$ The limit of quantification found was $2.50 \mu \mathrm{g} / \mathrm{L}$. The sensitivity of this method was similar or even higher than that of other published methods, for which the limit of quantification was $5.0 \mu \mathrm{g} / \mathrm{L}^{5,10,25,26}$
Tables 2 and 3 show the results obtained for samples submitted to the RP-HPLC method. In 30 determinations made with samples from 19 patients, the values ranged between 3.30 and $863 \mu \mathrm{g} / 24 \mathrm{~h}$. Regarding the reference value $(55.0 \mu \mathrm{g} / 24 \mathrm{~h}), 36.6 \%$ of the obtained results were suggestive of a Cushing's syndrome diagnosis. As these samples were obtained from patients under clinical evaluation, we were able to compare the results with the corresponding diagnoses, confirmed by the pathological, imaging, and petrosal sinus catheterism examinations.

The results of the samples numbered from 1 to 12 (Table 2) were evaluated for cortisol in serum and/or saliva and correspond to data supplied by the routine laboratory. Cortisol measurement by RIA was performed using an adapted laboratory routine..$^{21}$ The concentration in $\mu \mathrm{g} / \mathrm{dL}$ was calculated using the RIACALC software (WallacOy) and the results were corrected for the initial volume and the dilution of the samples. The serum cortisol levels within the clinical application interval lied between 2.00 and $25.0 \mu \mathrm{g} / \mathrm{dL}^{27,28}$, while, according to the literature, the morning levels of salivary cortisol in adults are higher than $486 \mathrm{ng} / \mathrm{dL}$, and the nocturnal concentrations vary from 36.4 to $302 \mathrm{ng} / \mathrm{dL} .{ }^{29}$ The samples numbered from 13 to 30 (Table 3) were evaluated for cortisol in total urine and, whenever possible, in serum. Discrepancy was observed in five (27.8\%) evaluations of this group.

The results obtained were evaluated for efficiency in screening for Cushing syndrome by establishing a specific cutoff score, as proposed in the literature. ${ }^{30}$ Thus, values of 100.0 and $69.0 \%$ were obtained for specificity and sensitivity, respectively; these parameters represent the ability of the method to recognize a truly negative or positive condition, respectively. Based on a conclusive diagnosis of Cushing's syndrome and using the statistical tool described above, we suggested a reference value which is appropriate for screening this syndrome by measuring free urinary cortisol. The proposed reference value is $50.0 \mu \mathrm{g} / 24 \mathrm{~h}$ which provides an increase of sensitivity to $75 \%$ without harming the analytical specificity. Similarly, a borderline value of $41.0 \mu \mathrm{g} / 24 \mathrm{~h}$ was found for free urinary cortisol. Therefore, results in the range from 41.0 to $50.0 \mu \mathrm{g} / 24 \mathrm{~h}$ are suggestive of Cushing's syndrome, however

Table 3. Results of free cortisol measurements by RP-HPLC and total cortisol by fluoroimmunoassay in urine samples from patients with confirmed and not confirmed diagnosis of autonomous cortisol secretion

\begin{tabular}{|c|c|c|c|c|}
\hline Sample & Urinary free cortisol $(\mu \mathrm{g} / 24 \mathrm{~h})$ & Total urinary cortisol $(\mu \mathrm{g} / 24 \mathrm{~h})$ & Serum cortisol $(\mu \mathrm{g} / \mathrm{dL})$ & Diagnosis \\
\hline 13 & 863 & $411 \times 10^{1}$ & ND & Cushing's disease \\
\hline 14 & 96.7 & 595 & ND & Cushing's disease \\
\hline 15 & 21.3 & 143 & ND & Not confirmed \\
\hline 16 & 65.7 & 405 & 19.2 & Cushing's disease \\
\hline 17 & 204 & $113 \times 10^{1}$ & 20.2 & Cushing's disease \\
\hline 18 & 26.1 & 18.0 & ND & Not confirmed \\
\hline 19 & 136 & 742 & 20.5 & Ectopic Cushing's syndrome \\
\hline 20 & 184 & 442 & 21.0 & Ectopic Cushing's syndrome \\
\hline 21 & 323 & 380 & 21.0 & Cushing's disease \\
\hline 22 & 20.9 & 312 & 5.20 & Cushing's disease \\
\hline 23 & 62.9 & 608 & ND & Ectopic Cushing's syndrome \\
\hline 24 & 84.4 & 567 & ND & Ectopic Cushing's syndrome \\
\hline 25 & 81.1 & 371 & 17.4 & Cushing's disease \\
\hline 26 & 15.7 & 810 & 16.6 & Cushing's syndrome by adrenal tumor \\
\hline 27 & 40.5 & 467 & 27.8 & Ectopic Cushing's syndrome \\
\hline 28 & 49.8 & 570 & 5.00 & Cushing's syndrome by adrenal tumor \\
\hline 29 & 111 & $136 \times 10^{1}$ & 29.3 & Cushing's disease \\
\hline 30 & 23.7 & 332 & 13.2 & Ectopic Cushing's syndrome \\
\hline
\end{tabular}


inconclusive, due to the possibility of false-positive (7\%) and -negative (19\%) results.

\section{CONCLUSION}

A method using RP-HPLC is proposed that was shown to be sensitive and specific for the determination of free urinary cortisol, with advantages over radioimmunoassay because it does not produce radioactive waste and is less time-consuming. The results obtained indicate that the proposed methodology can be useful as a diagnostic tool in patients suspected to have Cushing's syndrome. Further studies should be conducted for a better evaluation of the possibility of establishing a new reference value.

\section{ACKNOWLEDGEMENTS}

This study received financial support from Conselho Nacional de Desenvolvimento Científico e Tecnológico - CNPq (478243/2004-9).

\section{REFERENCES}

1. http://www.endocrine.niddk.nih.gov/pubs/cushings/cushings.htm, acessada em Fevereiro 2009.

2. Vieira, J. G. H.; Tachibana, T. T.; Noguti, K. O.; Ferrer, C. M.; Maciel, R. M. B.; J. Bras. Patol. 1999, 35, 71.

3. Ching, S. Y.; Lim, E. M.; Beilby, J.; Bhagat, C.; Rossi, E.; Walsh, J. P.; Pullan, P.; Ann. Clin. Biochem. 2006, 43, 402.

4. Lin, C.; Wu, T.; Machacek, D. A.; Jiang, N.; Kao, P. C.; J. Clin. Endocrinol. Metab. 1997, 82, 151

5. Taylor, R. L.; Machacek, D.; Singh, R. J.; Clin. Chem. 2002, 48, 1511.

6. Turpeinen, U.; Markkanen, H.; Välimäki, M.; Stenman, U.; Clin. Chem. 1997, 43, 1386.

7. Turpeinen, U.; Stenman, U. H.; Scand. J. Clin. Lab. Invest. 2003, 63, 143.

8. Gatti, R.; Cappellin, E.; Zecchin, B.; Antonelli, G.; Spinella, P.; Mantero, E.; De Palo, E. F.; J. Chromatogr.. B 2005, 824, 51.

9. Rouits, E.; Celle, M. B.; Morel, A.; Gamelim, E.; J. Chromatogr., B 2003, 793, 357.

10. Furuta, T.; Mori, C.; Suzuki, A.; Shibasaki, H.; Yokokawa, A.; Kasuya, Y.; J. Chromatogr., B. 2004, 801,165.
11. Al Sharef, O.; Feely, J.; Kavanagh, P. V.; Scott, K. R. Sharma, S. C.; Biomed. Chromatogr. 2007, 21, 1201.

12. Vieira, J. G. H.; Nakamura, O. H.; Cravalho, V. M.; Arq. Bras. Endocrinol. Metab. 2005, 49, 291.

13. Shibasaki, H.; Furuta, T.; Kasuya, Y.; J. Chromatogr., B 1997, 692, 7.

14. Furuta, T.; Matsuzawa, H.; Kasuya, Y.; J. Chromatogr., B 2000, 738, 367.

15. Palermo, M.; Shackleton, C. H.; Mantero, F.; Stewart, P. M.; Clin. Endocrinol. 1996, 45, 605.

16. Wood, L.; Ducroq, D. H.; Fraser, H. L; Gillingwater, S.; Evans, C.; Pickett, A. J.; Rees, D. W.; John, R.; Turkes, A.; Ann. Clin. Biochem. 2008, $45,380$.

17. Soldin, S. J.; Soldin, O. P.; Clin. Chem. 2009, 55, 1061.

18. Fernandes, V. T.; Ribeiro-Neto, L. M.; Lima, S. B.; Vieira, J. G. H.; Verreschi, I. T. N.; Kater, C. E.; J. Chromatogr. Sci. 2003, 41, 251.

19. Sugawara, E. K.; Ribeiro-Neto, L. M.; Fernandes, V. F. T.; Kater, C. E.; Verreschi, I. T. N.; Rev. Bras. Cien. Farm. 2004, 40, 327.

20. Vieira, J. G. H.; Russo, E. M. K.; Maciel, R. M. B.; Germek A. O.; Antunes, L. A. N.; Rev. Bras. Patol. Clin. 1979, 15, 125.

21. Wei, J. Q.; Wei, J. L.; Zhou, X. T.; Cheng, J. P.; Biomed. Chromatogr. 1990, 4,161 .

22. Sugawara, E. K.; Ribeiro Neto, L. M.; Oliveira, K. C.; Verreschi, I. T. N.; J. Bras. Patol. Med. Lab. 2008, 44, 337.

23. Aburuz, S.; Millership, J.; Heaney, L.; Mcelnay, J.; J. Chromatotogr., $B$ 2003, 798, 193

24. Hu, Z.; Gong, Q.; Hu, X.; Wang, L.; Cao, Y.; Cao, W.; Yu, Q.; Cheng, Z.; J. Chromatogr., B 2005, 826, 238.

25. Zhang, Y.; Wu, H. L.; Ding, Y. J.; Xia, A. L.; Cui, H.; Yu, R. Q.; J. Chromatogr., $B$ 2006, 840, 116

26. Nassar, A. E.; Varshney, N.; Getek, T.; Cheng, L.; J. Chromatogr. Sci. 2001, 39, 59 .

27. http://www.fleury.com.br/Sist/manual_exames/Pages/Coleta. aspx? usuario=medico, acessada em Novembro 2007.

28. http://www.mayomedicallaboratories.com/test-catolog/ Clinical+and+Interpretive/8545, acessada em Junho 2009

29. Kiess, W.; Ptaffle, R.; J. Pediatr. 2007, 83, 97.

30. Portney, L. G.; Watkins, M. P.; Foundations of Clinical Research Applications to Practice, $1^{\text {st }}$ ed., Appleton \& Lange: Connecticut, 1993, cap. 6. 